\title{
Analyses of permeability and porosity of sedimentary rocks in terms of unconventional geothermal resource explorations in Poland
}

\author{
Anna Sowiżdżał* \& Roman Semyrka \\ AGH University of Science and Technology, Faculty of Geology, Geophysics and Environmental Protection, \\ Department of Fossil Fuel, Al. Mickiewicza 30, 30- 059 Kraków, Poland \\ * corresponding author: e-mail: ansow@agh.edu.pl
}

\begin{abstract}
Petrophysical investigations are fundamental to natural resource exploration. In order to recognise the geothermal potential of sedimentary rocks in central Poland, 259 samples were collected from prospective deep-lying geothermal reservoirs. Parameters measured include bulk density, skeletal density, effective porosity, permeability, average pore diameter and specific surface. Results indicate that at great depths (mostly $>3,000 \mathrm{~m}$ below surface) sedimentary rocks show low values of porosity (mainly less than $5 \%$ ) and permeability (only sporadically in excess of $1 \mathrm{md}$ ). These values call for a petrothermal use of reservoirs, for which an Enhanced Geothermal System (EGS) was developed. Reservoirs suited for the EGS are Carboniferous and Lower Triassic sandstones in the central part of Poland (Mogilno-€ódź Trough region and a small part of the Kujawy Swell and Fore-Sudetic regions). In addition, Carboniferous limestones in this area are potentially prospective.
\end{abstract}

Keywords: petrophysical parameters, geothermal energy, Enhanced Geothermal Systems, central Europe

\section{Introduction}

In Poland geothermal interest has grown since the 1960s (Dowgiałło, 1969; Dowgiałło et al., 1969; Dowgiałło, 1972; Čermak, 1979). Initially, projects focused on the study of geothermal fields within geological units. The first research projects devoted to an assessment of the possibility for utilisation of hot groundwaters and geothermal energy were undertaken in the 1980s at the AGH University of Science and Technology in Kraków (Ney \& Sokołowski, 1987). Resulting from a number of studies and geothermal projects carried out since that time, hydrogeothermal resources are relatively well recognised (Górecki et al., 1990-2013, Hajto \& Górecki, 2005, 2010; Sowiżdżał, 2012, 2015) as are their possible uses (Papiernik et al., 2008; Sowiżdżał, 2010; Tomaszewska \& Szczepański, 2014).
It has been shown that Poland is situated in the zone of low-temperature geothermal resources. Today, geothermal waters are used in several geothermal heating plants and a number of extensive recreational centres and balneotherapeutic facilities. However, geothermal resources are not used for the production of electricity, although studies into this are in progress (Bujakowski \& Tomaszewska et al., 2014; Miecznik et al., 2015). In many regions, problems arise from the low production rates of wells as a result of the worst petrophysical parameters of reservoir rocks (i.e., low values of permeability and porosity). Improvement of EGS technology has caused that just the low values of porosity and permeability, together with appropriate thermal conditions and rock fracturability, are suitable for development of petrogeothermal resources. Adequate recognition of such resources is dependent 


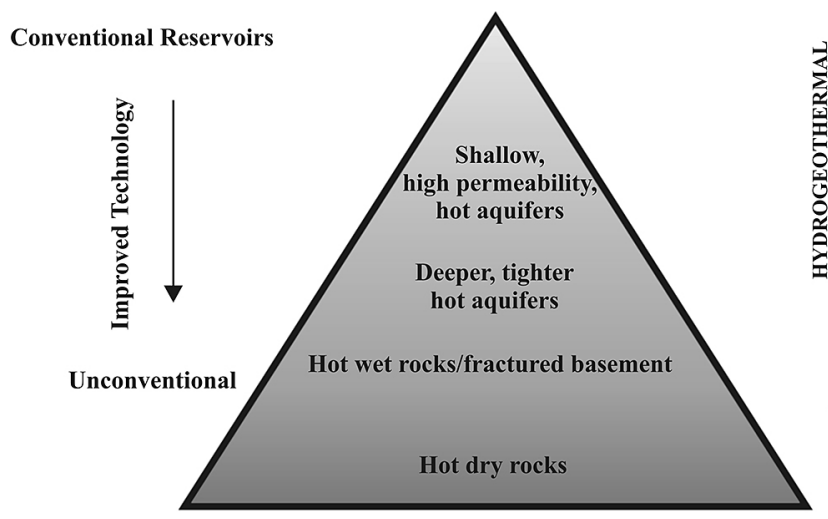

of, among other factors, analysis of petrophysical parameters of reservoir rocks.

Originally, petrogeothermal resource was considered a resource distinct from conventional geothermal energy. Types of geothermal resources are shown in Figure 1. The resource pyramid concept suggests that there is a limited amount of prime resources that are easy to extract. There is also a much larger volume of resources that are technologically more difficult to access. Over time, resources near the top of the pyramid are depleted and technological developments lead to resources further down the pyramid being developed cost effectively (Hillis et al., 2004).

The technology of development of conventional geothermal resources (both low- and high-temperature ones) is well known and extensively available. Since the 1970s (the first project led by the Los Alamos National Laboratory, USA) also utilisation of deeper-lying unconventional resources (hot dry or wet rocks) using the Enhanced Geothermal Systems (EGS) has been progressively developed (Tester et al., 2006). The EGS cost cannot yet be assessed accurately because of the limited experience derived from pilot plants, but it appears to become competitive in the near future. The world predictions indicate that petrogeothermal energy is the type of the future and that in the coming years development of this energy sector may be expected (EGEC, 2013).

EGS provide a means of using geothermal energy when hydrothermal conditions are not ideal, that is, when natural conditions in the host rock do not provide sufficient fluid content and/or connected permeability. The idea behind EGS is to emulate what nature provides in high-grade hydrothermal reservoirs at depths where rock temperatures are sufficient for power or heating applications. A fractured reservoir is stimulated hydraulically and connected to injection and production wells separated by sufficient distances to yield a sustainable system for extracting thermal energy stored in the rock (Horne \& Tester, 2014). Enhanced Geothermal Sys-
Fig. 1. Geothermal resource pyramids (from Hillis et al., 2004).

tems will greatly increase the geothermal potential as it allows for production of geothermal electricity nearly anywhere in Europe, including Poland, with medium and low temperature (EGEC, 2013).

In 2010-2013 a research project intended to gauge the potential of hot dry rocks for heat and electricity production in Poland was carried out by leading scientific centres (the research consortium consisted of the Polish Geological Institute - National Research Institute, the AGH University of Science and Technology - AGH-UST, the Mineral and Energy Economy Institute of the Polish Academy of Sciences, and the PBG Geophysical Exploration Co Ltd.). The main objective of this project was to assess, by cartographic mapping, the possibility of using geological successions in an EGS development. The goal of the research conducted by the AGHUST team was to indicate the best location for EGS in sedimentary rocks (Górecki et al., 2013; Sowiżdżał et al., 2013; Sowiżdżał \& Kaczmarczyk, 2016).

The aim of the present paper is to list permeability and porosity of deep-seated hot dry rocks in central Poland. For their unconventional resources they were initially eliminated from potentially prospective regions for utilisation of geothermal energy. However, most recent researches conducted within the framework of the project 'Evaluation of potential, thermal balance and prospective geological structures for needs of closed geothermal systems (Hot Dry Rocks) in Poland' highlight their potential for EGS technology.

\section{Geological background}

The area selected for detailed analyses in terms of a preliminary assessment of potential EGS development covered the central part of Poland (SzczecinMogilno-Łódź Trough region and a small part of the Kujawy Swell and Fore-Sudetic regions) (Fig. 2). The former area is part of a belt of troughs that stretches from the northwest to southeast. This belt, known as 
Fig. 2. Location of cored wells for analyses; geothermal installations in Poland also are shown (based on Kępińska, 2015).

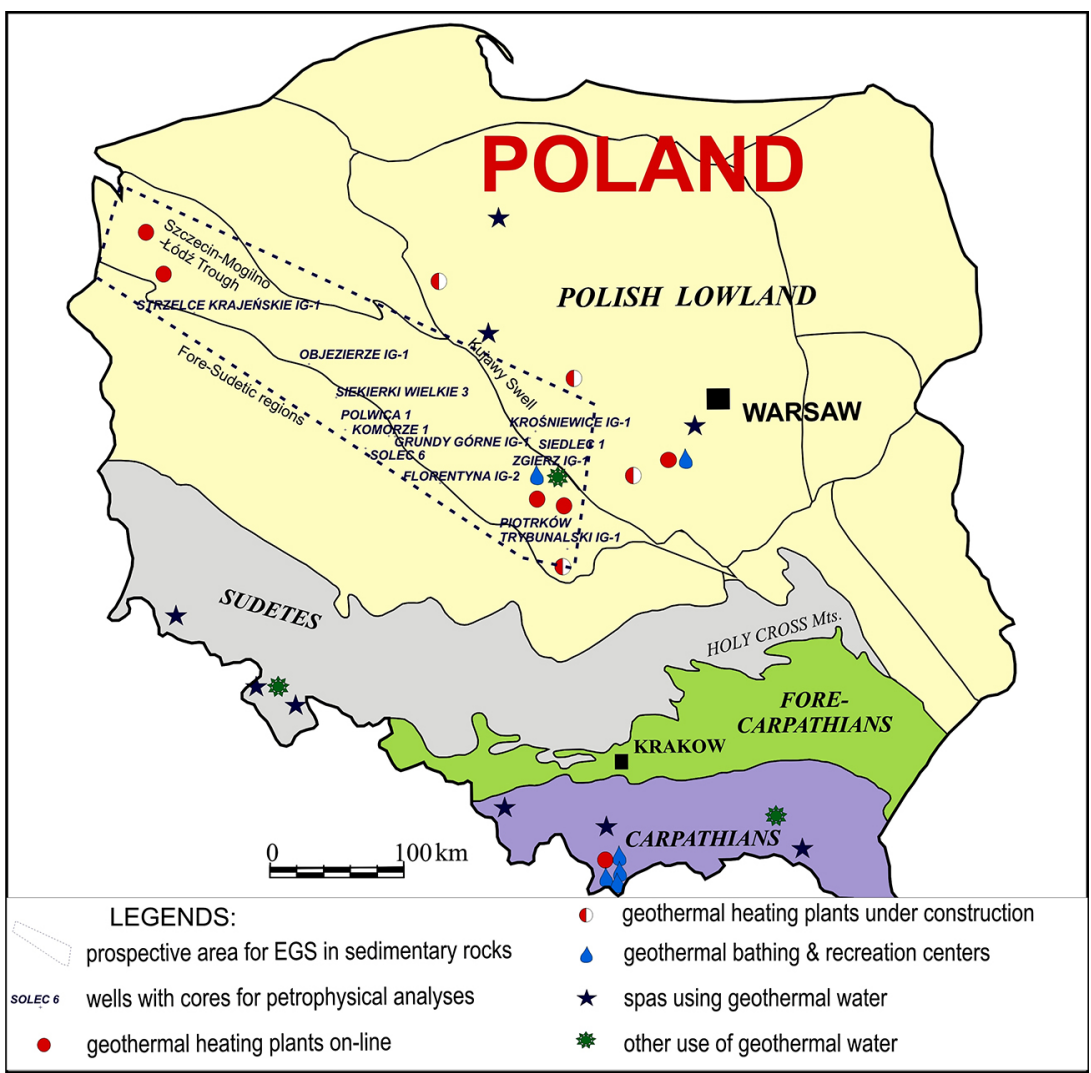

the Szczecin-Mogilno-Łódź-Miechów Trough (Synclinorium), extends along the southwestern flank of the Mid-Polish Swell, a part of which is represented by the Kujawy Swell. This synclinorium can be divided into three distinct troughs: the Szczecin, Mogilno-Łódź Trough and Miechów troughs, which are separated by horsts of Jurassic rocks below the sub-Cenozoic surface (Karnkowski, 2008; Doornenbal et al., 2010; Mizerski, 2011).

The Szczecin-Mogilno-Łódź-Miechów Trough is filled with the Upper Cretaceous rocks resting on older rocks which crop out under the sub-Cenozoic surface along the southwestern flank of the Mid-Polish Swell, on the Fore-Sudetic Monocline and on horsts. The Permian-Mesozoic cover, which comprises sediments that fill up the Mogilno-Łódź Trough, and occur in the Fore-Sudetic Monocline and Kujawy Swell zones, rests on Rotliegend, Upper and Lower Carboniferous, Devonian, Silurian, Ordovician and Cambrian sequences that rest on crystalline and effusive rocks of the Precambrian basement. In the study area, units of the Variscan orogeny (Variscan externides) have been poorly recognised due to the great thickness of the Permian-Mesozoic cover (Narkiewicz \& Dadlez, 2008; Mizerski, 2011).

Vertical movements of blocks in the sub-Zechstein basement, superimposed by deformations caused by movements of the Zechstein salt masses, were the main factors that shaped the present-day structure of the Permian-Mesozoic complex. In the lower part of this complex, thick beds of Zechstein salt became plastic under the influence of accretion of younger sediment series. Therefore they could move, which impacted subsequent sedimentation (changes in thickness and facies, formation of erosional surfaces and sedimentary gaps) and caused mechanical deformation of the overburden. The area of the strongest impact of salt tectonics in Poland covers the Kujawy region and adjacent regions where there is a zone of salt plugs that penetrate rocks up to the sub-Cenozoic surface or salt plugs and salt horsebacks (elongated salt plugs) that in part do so. This zone is surrounded by a zone of weaker effects of such tectonics, which manifests itself by the occurrence of salt swells and salt pillows (Dadlez et al., 1998).

Based on experience made in other parts of the world (Tenzer, 2001; Tester et al., 2006; Sausse et al., 2007; Antkowiak et al., 2010; Brown et al., 2012) the sedimentary rocks in the regions selected meet the following critical requirements for EGS: thermal parameters of the rocks (i.e., temperatures $>150^{\circ} \mathrm{C}$ ); thickness of the reservoir (minimum $300 \mathrm{~m}$ ); porosity and permeability of reservoir rocks (as the lowest); reservoir depth (up to $6 \mathrm{~km}$ ). Because of 
Table 1. Thermostratigraphy of potential rock reservoirs for EGS systems in central Poland.

\begin{tabular}{|c|c|c|c|c|}
\hline $\begin{array}{l}\text { Strati- } \\
\text { graphic } \\
\text { identi- } \\
\text { fier }\end{array}$ & Stratigraphy & $\begin{array}{c}\text { Depth } \\
{[\mathrm{km}} \\
\text { b.s.l. }]\end{array}$ & $\begin{array}{l}\text { Maxi- } \\
\text { mum } \\
\text { tempera- } \\
\text { ture } \\
\text { at the top } \\
\text { of the } \\
\text { reservoir } \\
{\left[{ }^{\circ} \mathrm{C}\right]}\end{array}$ & $\begin{array}{l}\text { Total } \\
\text { thickness } \\
\text { of the } \\
\text { reservoir } \\
\text { [m] }\end{array}$ \\
\hline $\mathrm{T} 2$ & Middle Triassic & $0.5-5$ & 160 & $300-1000$ \\
\hline $\mathrm{T} 1$ & Lower Triassic & $1-6$ & 180 & $300-2000$ \\
\hline P1 & Lower Permian & $3-6$ & 190 & $300-500$ \\
\hline $\mathrm{C} 1$ & Carboniferous & $3-6$ & 200 & $300-2500$ \\
\hline
\end{tabular}

hydrofracturing importance in the reservoir rocks, compact sandstones or limestones have been considered the most appropriate for mechanical properties.

Thermostratigraphy (Table 1) (Wójcicki et al., 2013) as well as surface heat flow density map (60100 mW/m²) (Szewczyk \& Gientka, 2009) evidence conditions favourable for EGS systems in the Polish Lowlands. In particular, dense sandstones and dense, slightly fractured limestones and dolomites of Triassic age (mainly Early Triassic but locally also Middle), the Lower Permian and Carboniferous formations are considered potential rock reservoirs for EGS systems.

The Carboniferous strata are developed as follows: in the area of the post-orogenic molasses (to the east and northeast of Poznań, and in the Konin, Sieradz, Łódź and Piotrków Trybunalski areas) - as the flysch lithofacies, so-called exoflysch (debrites, turbidites); in the area of the Kujawy Swell - as sandstones, siltstones and claystones (pseudoflysch), and as sandstones and siltstone-claystone deposits (Narkiewicz \& Dadlez, 2008).

The Lower Permian is represented by terrigenous deposits that formed in a desert, i.e., under dry and hot climatic conditions. They typically form thick complexes of vari-grained rocks which are diagonally bedded or lumpy. In the Polish Lowlands, Lower Permian formations rest, with a distinct sedimentary gap, on basement rocks characterised by the Variscan and Caledonian consolidation. Among the Rotliegend formations, Autunian effusive rocks (in the western part of Poland) play an important role. The Saxonian deposits are widely distributed and developed as facies of red clastic rocks. In the Saxonian section, a number of sedimentary cycles can be distinguished, the succession of which is sandstone - siltstone - claystone (Dadlez et al., 1998).
The Lower Triassic is represented by lower, middle and upper Buntsandstein rocks which in a major part of the Polish Lowlands are developed as a lithofacies with a predominance of claystone-siltstone deposits. In the lower Buntsandstein of the southern part of the Polish Lowlands basin, sandy fluvial and (less frequently) aeolian deposits occur. In the remaining area of Poland, the Lower Buntsandstein is developed as a monotonous complex of claystone-siltstone rocks with interbeds of oolitic limestones (except for the eastern part of the Mogilno-Łódź Trough) and sandstones. The middle Buntsandstein in the southern part of the basin is represented by sandstones and siltstones. In the Fore-Sudetic Monocline area, sandstones are dominant and towards the Mid-Polish Swell they pass into clayey sediments. The upper Buntsandstein is analysed together with the Muschelkalk (T2+Tp3) in consideration of its predominant carbonate development, whereas sandstones of the lower and middle Buntsandstein (Tp1+Tp2) are treated as prospective formations of the Lower Triassic (Szyperko-Teller, 1997).

The Middle Triassic is represented by the Muschelkalk which can be divided into the lower, middle and upper Muschelkalk. The lower Muschelkalk of the Mogilno-Łódź Trough is developed as grey and beige limestones, often bedded and laminated with claystones and marls. In the northern part of the Kujawy Swell, marly and dolomitic limestones predominate. The middle Muschelkalk, represented by interbedded dolomitic claystones, dolomitic marls and anhydrites, reveals a relatively homogeneous development over vast areas. As a rule, the upper Muschelkalk is composed of limestones in the lower part of the section and claystones with small limestone intercalations in the upper part. This lithological type is characteristic of the upper Muschelkalk in the Mogilno-Łódź Trough. In the area under discussion, the Middle Triassic is represented by the Muschelkalk that is divided into the Lower, Middle and Upper Muschelkalk. In the Mogilno-Łódź Trough, the Lower Muschelkalk is formed of grey and beige limestones, often bedded and laminated with claystones and marls. In the northern part of the Kujawy Swell, marly and dolomitic limestones are dominant. The middle Muschelkalk, represented by intercalated dolomitic claystones, dolomitic marls, dolomites and anhydrites, shows a relatively homogeneous development over large areas. The upper Muschelkalk, as a rule, is composed of limestones in the lower part of its section, and of claystones with thin limestone interlayers in the upper part. Such a lithology is characteristic of the Muschelkalk in the Mogilno-Łódź Trough (Gajewska, 1997). 


\section{Analyses}

In order to recognise petrophysical parameters of rocks that form potential reservoirs for EGS, 259 samples of sedimentary rocks were taken from 12 wells located in the study area (Fig. 2). For these, 259 porosimetric analyses and 57 permeability parameter measurements were carried out. Three types (facies) of sedimentary rocks were analysed: terrigenous (arenites, arkoses, subarkoses), mudstones (siliceous, siliceous-clayey, calcareous, calcareous-clayey, clayey-ferruginous, clayey, clayey-siliceous, calcareous, calcareous-ferruginous, fine- and coarse-grained mudstones) and carbonate (dolomites and micritic, micritic-sparitic, sparitic and microsparitic limestones).

\subsection{Porosity}

Porosity measurement was performed by mercury porosimetry. In this method, values of effective porosity obtained are a function of bulk density, skeletal density, specific surface of the pore space, and predominant proportion of pores with a determined diameter. Furthermore, the method allows determination and indication of a type of the pore space: simple (porous or fractured pore space) or mixed (porous-fractured pore space) (Tiab \& Donaldson, 2004; Giesche, 2006; Semyrka et al., 2008). The essence of the method is based on the assumption that capillary pressures result from interaction between forces acting within a liquid (i.e., cohesion) and forces between liquids saturating the pore space and the rock framework itself (i.e., adhesion). When adhesive forces prevail over cohesive forces, a liquid (e.g., water) is "wetting"; in an inverse relation, a liquid is "non-wetting". Relative wettability of fluids is determined by contact angle between the solid and the wetting/non-wetting liquid interface. In capillary pores, the wetting liquid rises above the interface as a result of adhesion, up to achievement of equilibrium between adhesive forces and gravitational forces (Kuśmierek \& Semyrka, 2003).

Quantitative and qualitative investigations of pore space in samples from the cores analysed were conducted using the Auto Pore 20 mercury porosimeter from Micromeritics at the AGH-UST in Kraków. In this apparatus, computer-assisted mercury injection was applied, from a pressure lower than ambient pressure up to $6 \cdot 10^{4}$ psi (i.e. 413.4 $\mathrm{MPa})$, which allows for penetration of voids from $0.003 \mu \mathrm{m}$ up to $360 \mu \mathrm{m}$.

\subsection{Permeability}

Determination of the effective permeability coefficient was performed by applying the gas method. The measuring principle consists in bringing steady laminar flow of gas through the test sample (working gas is nitrogen) and calculate the coefficient of permeability using the Darcy equation.

\section{Results}

Table 2 lists results of laboratory tests on rock samples (average values), within the scope of a quantitative assessment values of the following petrophysical parameters were obtained, i.e. bulk density $\left(\rho_{\mathrm{o}}\right)$, skeletal density $\left(\rho_{\mathrm{s}}\right)$, effective porosity $(\varphi)$, pore diameters $(\Phi)$, specific surface $(S)$ and permeability $(\mu)$, while the qualitative assessment characterised types of pore space in rocks. Selected results of porosimetric investigations of rocks are illustrated in Figures 3-6. Below we outline these results, indicating reservoirs of different lithology and age.

\subsection{Middle Triassic deposits}

Middle Triassic deposits (T2) have been penetrated in the Florentyna IG-2, Grundy Górne IG1(Fig. 3), Krośniewice IG-1, Piotrków Trybunalski IG-1, Siedlec 1, Strzelce Krajeńskie IG-1 and Zgierz IG-1 wells. These comprise:

- a carbonate facies - rocks with very low porosity $(\varphi=0.85-1.72 \%)$, micropermeable $(\mu=0.10$ md) and poorly permeable $(\mu=3.5 \mathrm{md})$, with porous-fractured type II reservoir pore space in cores from the Florentyna IG-2, Krośniewice IG-1, Grundy Górne IG-1 and Siedlec 1 wells;

- a mudstone facies - rocks with very low porosity $(\varphi=1.49-3.30 \%)$, micropermeable $(\mu=1 \mathrm{md})$, with porous-fractured and subordinately fractured type II/I reservoir pore space in the Krośniewice IG-1, Siedlec 1 and Strzelce Krejeńskie IG-1 wells, and low porosity in the borehole Piotrków Trybunalski IG-1 $(\varphi=7.61 \%)$, and very low permeability in the order of $0.0001 \mathrm{md}$; - a terrigenous facies (very fine-grained subarkoses), recognised in the Krośniewice IG-1 well - rocks with very low porosity $(\varphi=6.73 \%)$, micropermeable $(\mu=0.03 \mathrm{md})$, with porous type I and fractured-porous type II reservoir pore space. 


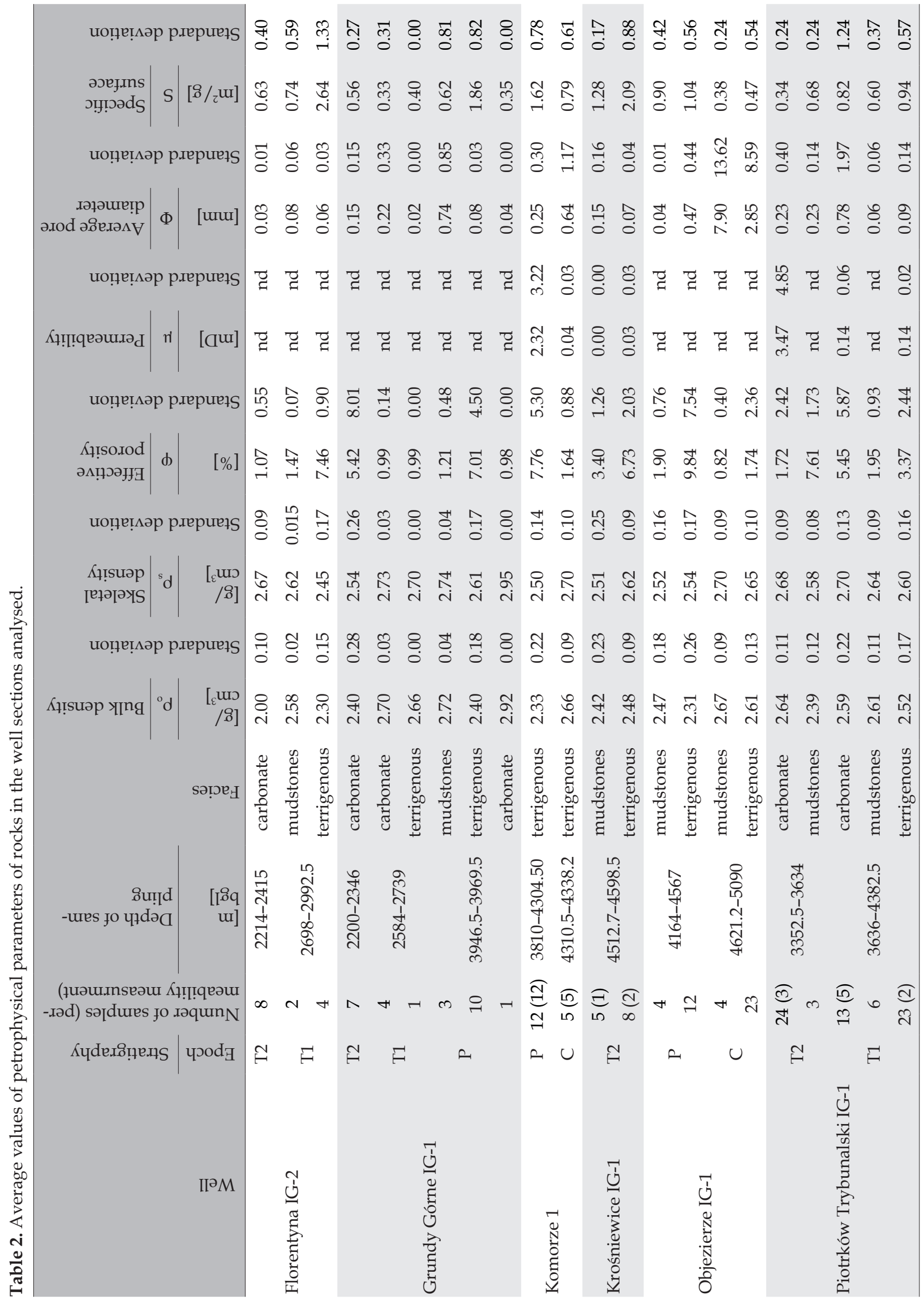




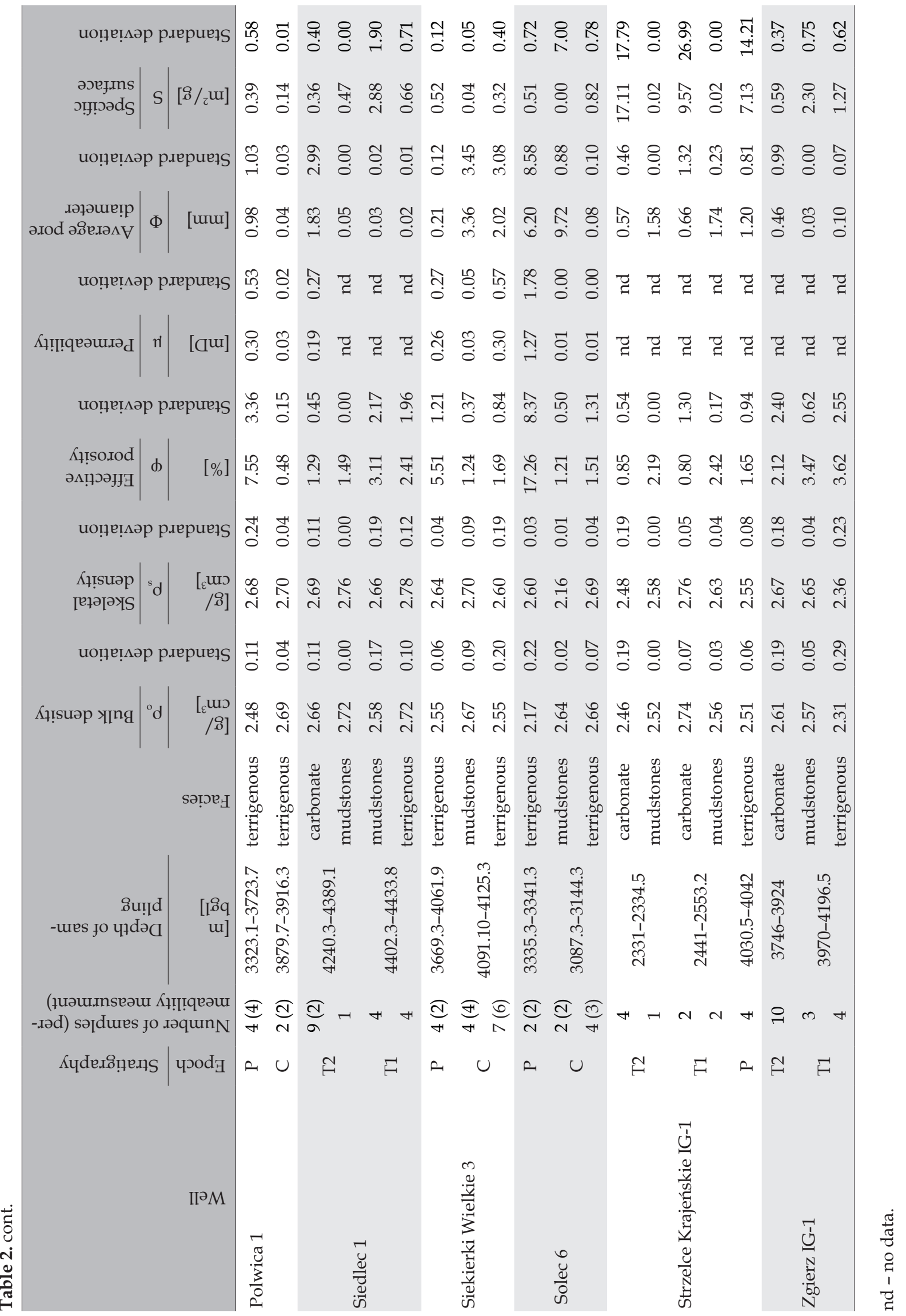



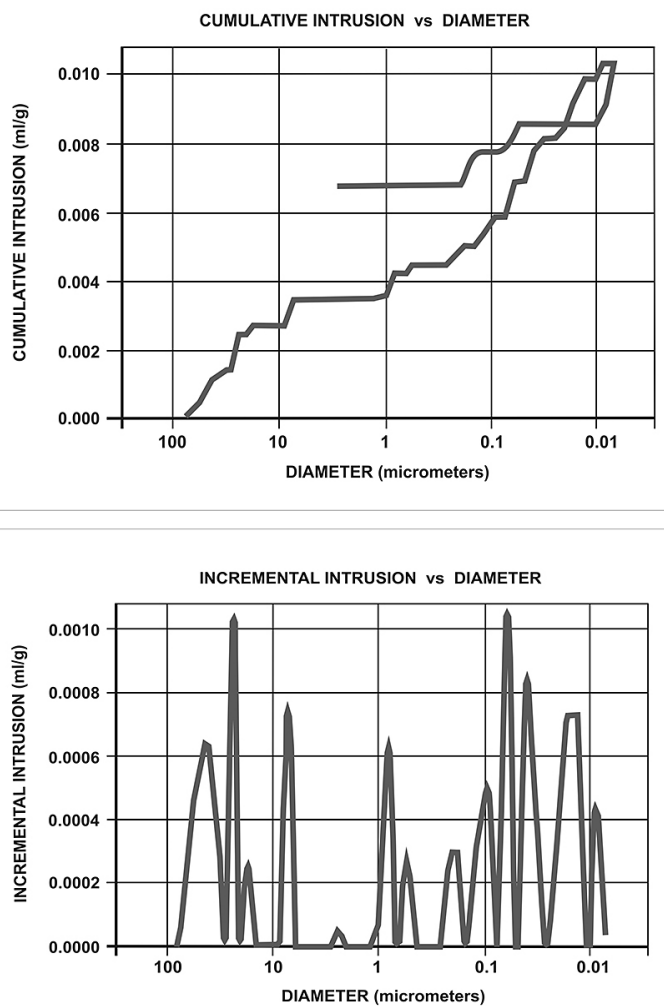

\subsection{Lower Triassic deposits}

Lower Triassic deposits (T1) have been identified in the Florentyna IG-2, Grundy Górne IG-1, Piotrków Trybunalski IG-1(Fig. 4), Siedlec 1 and Strzelce Krajeńskie IG-1 wells. They are developed in:

- a mudstone facies - rocks with very low porosity $(\varphi=1.47-3.11)$, mostly with fractured type III and subordinately porous-fractured type II reservoir pore space;

- a terrigenous facies - generally low-porosity rocks, with fractured and porous-fractured reservoir pore space, except for the Florentyna IG-2 well which reveals low porosity, mostly with fractured reservoir pore space;

- a carbonate facies - rocks with very low porosity, mostly with fractured reservoir pore space. Only the Piotrków Trybunalski IG-1 well section departs from this picture, having revealed low porosity of deposits;

\subsection{Permian deposits}

Permian strata $(\mathrm{P})$ have been encountered in the Grundy Górne IG-1, Komorze 1 (Fig. 5), Objezi-
Effective porosity $\varphi=2.69 \%$

Apparent (skeletal) density $\rho_{s}=\mathbf{2 . 6 1} \mathrm{g} / \mathrm{cm}^{3}$

Bulk density $\rho_{o}=2.68 \mathrm{~g} / \mathrm{cm}^{3}$

Average capillary diameter $\Phi=0.0521 \mu \mathrm{m}$

Total pore area $\mathrm{S}=0.789 \mathrm{~m}^{2} / \mathrm{g}$

Type of the pore space: fractured (III)
Fig. 3. Results of porosimetric investigations of Middle Triassic (Muschelkalk) rocks in the Grundy Górne IG-1 well (sample of microsparitic limestones from a depth of $2,346.0 \mathrm{~m})$.

erze IG-1, Polwica 1, Siekierki Wlk. 3, Solec 1 and Strzelce Krajeńskie wells, as:

- a terrigenous facies - mainly arenites and subarkoses with low porosity, with porous and sporadically fractured or porous-fractured reservoir pore space. Only in the distant Strzelce Krajeńskie IG-1 well are there rocks with very low porosity and fractured reservoir pore space;

- a mudstone facies, occurring only in the neighbouring Grundy Górne IG-1 and Objezierze IG-1 wells. These are rocks with very low porosity and composite fractured-porous reservoir pore space;

- a carbonate facies with very low porosity and fractured reservoir pore space, identified only in the Grundy Górne IG-1 well.

\subsection{Carboniferous deposits}

Carboniferous rocks (C) have been encountered in the Komorze-1, Objezierze IG-1 (Fig. 6), Polwica-1, Siekierki Wielkie-3 and Solec-6 wells. They are developed in:

- a terrigenous facies - arenites and subarkoses with low porosity $(0.48<\varphi<1.7 \%)$, micropermeable (below $0.3 \mathrm{md}$; mostly $0.1 \mathrm{mD}$ ), with 
Fig. 4. Results of porosimetric investigations of Buntsandstein rocks in the Piotrków Trybunalski IG-1 well (sample of micritic limestones from a depth of 3,746 m).
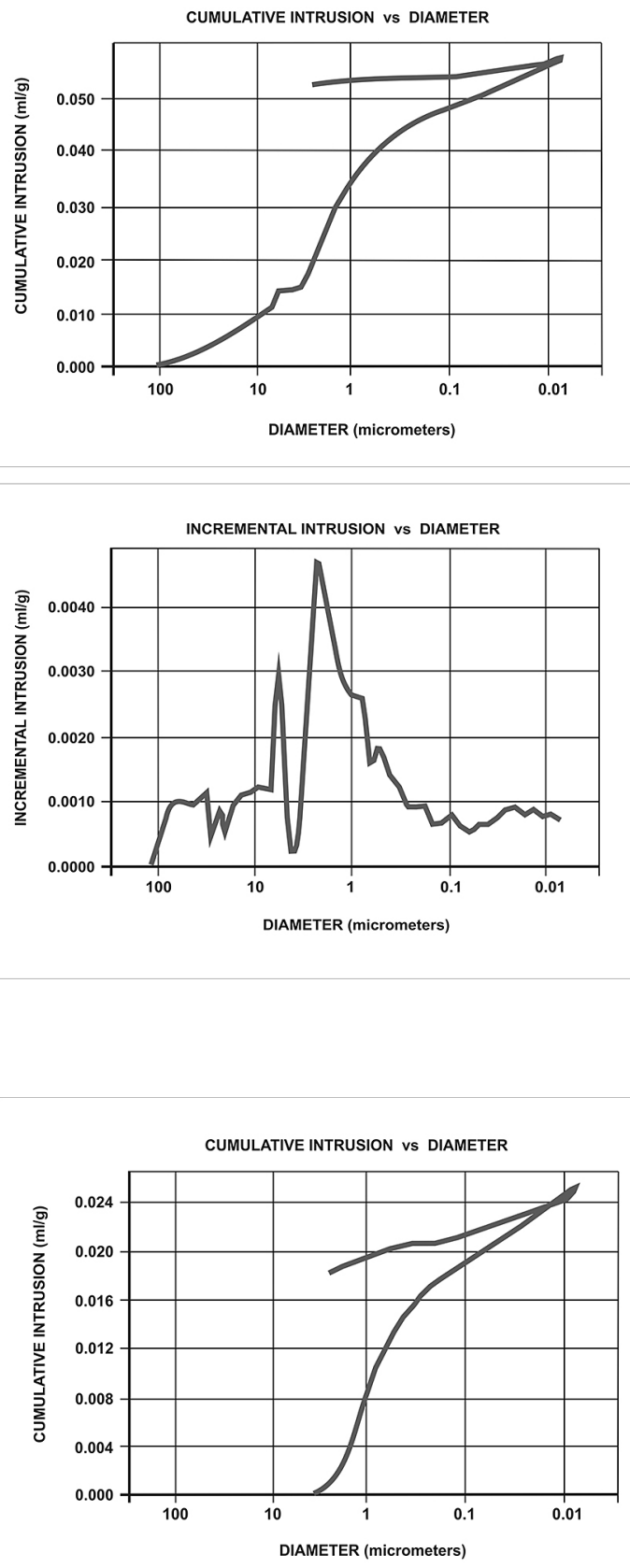

INCREMENTAL INTRUSION vs DIAMETER

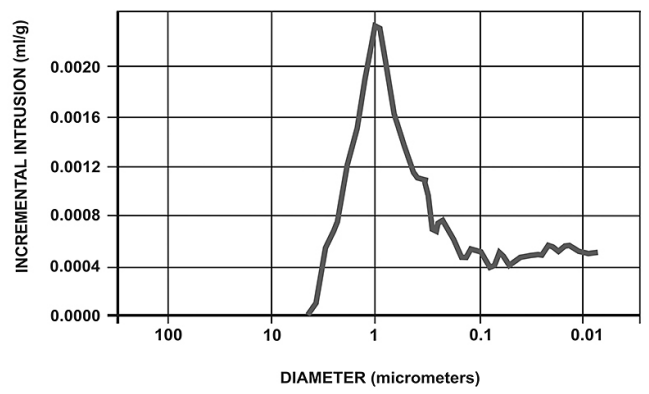

Effective porosity

$\varphi=13.02 \%$

Apparent (skeletal) density $\rho s=2.27 \mathrm{~g} / \mathrm{cm}^{3}$

Bulk density

$\rho_{0}=2.68 \mathrm{~g} / \mathrm{cm}^{3}$

Average capillary diameter $\Phi=\mathbf{0 . 1 1 1 8} \mu \mathrm{m}$

Total pore area $\mathrm{S}=2.054 \mathrm{~m}^{2} / \mathrm{g}$

Type of the pore space: porous - fractured (III)
Fig. 5. Results of porosimetric investigations of Permian rocks in the Komorze-1 well (sample of finegrained arenite from a depth of $4,304.5 \mathrm{~m})$.
Effective porosity $\varphi=5.81 \%$

Apparent (skeletal) density $\rho s=2.31 \mathrm{~g} / \mathrm{cm}$

Bulk density $\rho_{o}=2.40 \mathrm{~g} / \mathrm{cm}^{3}$ Average capillary diameter $\Phi=0.0740 \mu \mathrm{m}$

Total pore area $\mathrm{S}=1.362 \mathrm{~m}^{2} / \mathrm{g}$

Type of the pore space: porous (I) 

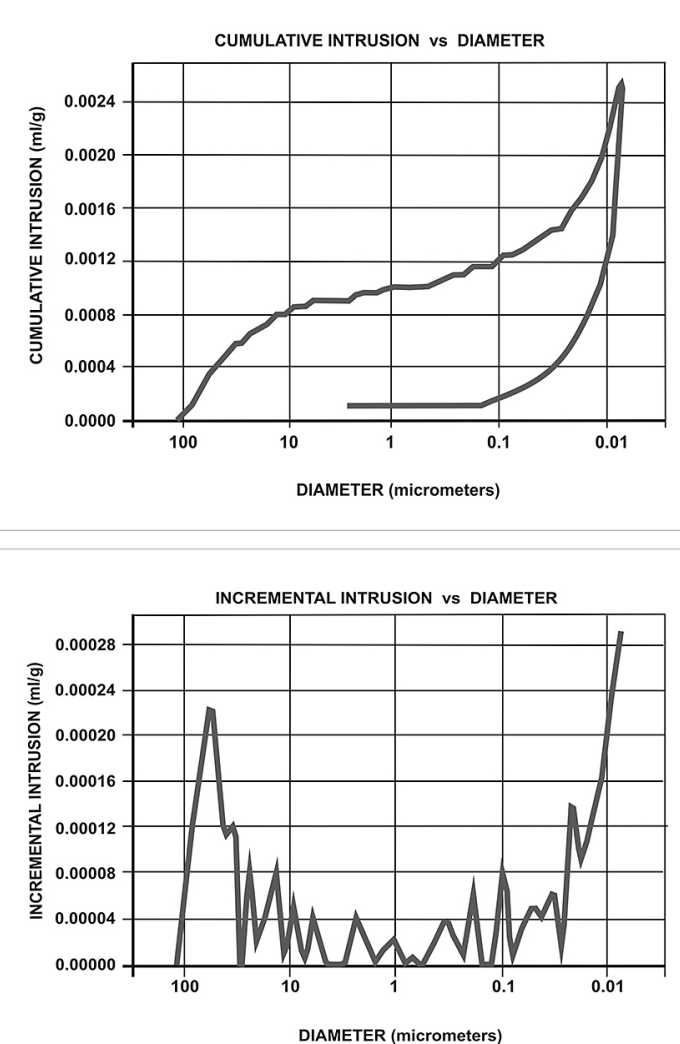

fractured-porous type II and subordinately fractured type III reservoir pore spaces;

- a mudstone facies with low porosity and fractured reservoir pore space $(0.82<\varphi<1.24 \%)$ and low permeability (below $0.03 \mathrm{mD}$ ), fractured-porous type II, subordinately fractured type III or porous type III reservoir pore spaces.

\section{Discussion}

The rocks examined are essentially sedimentary. For this purpose, both types of sedimentary rock and places of their occurrence were considered. Samples of rocks analysed were taken from various depths between 2,200 and 5,090 m below surface. (interval 4,621.2-5,090 m). Carboniferous deposits (mudstones and terrigenous rocks) in the Objezierze IG-1 well were the deepest-lying strata, while Middle Triassic carbonate deposits identified in the Strzelce Krajeńskie IG-1, Florentyna IG-2 and Grundy Górne IG-1 wells occurred in the shallowest zone.

Among 259 samples of sedimentary rocks taken from 12 wells in the study area 82 samples represented carbonate deposits, 44 mudstones and 133 terrigenous deposits. Carbonate rocks occur main-
Effective porosity $\varphi=0.67 \%$

Apparent (skeletal) density $\rho s=2.69 \mathrm{~g} / \mathrm{cm}^{3}$

Bulk density $\rho_{0}=2.71 \mathrm{~g} / \mathrm{cm}^{3}$ Average capillary diameter $\Phi=0.0256 \mu \mathrm{m}$

Total pore area $\mathrm{S}=0.390 \mathrm{~m}^{2} / \mathrm{g}$

Type of the pore space: porous - fractured (III)

Fig. 6. Results of porosimetric investigations of Carboniferous rocks in the Objezierze IG-1 well (sample of mudstone from a depth of $4,676.5 \mathrm{~m})$.

ly within Triassic reservoirs, while terrigenous and mudstone rocks occur in all reservoirs analysed.

The rocks studied are low to very low porous, have low permeability and sporadically have fractures. These rocks are characterized by absence or low content of water (Tiab \& Donaldson, 2004). These features differ widely from conventional conditions useful for operable geothermal systems (Górecki et al., 2006a). However, the rocks studied are mostly appropriate for unconventional geothermal systems (Tester et al., 2006; Brown et al., 2012). In particular, high values of reservoir parameters of rocks (both effective porosity and permeability) are characteristic of Permian sandstones (favourable for conventional geothermal systems), whereas relatively low values of the parameters analysed (favourable for EGS systems) are related to Carboniferous and Lower Triassic sandstones. The average porosity of terrigenous rocks is in the range of $0.5 \%$ to $10 \%$, with one exception $(>17 \%$; Permian deposits in the Solec-6 well; see Table $2)$. The maximum porosity value $(29 \%)$ has been measured for a Permian sandstone sample in the Objezierze IG-1 well at a depth of 4,165 m below surface (Fig. 7A). The average porosity of carbonate rocks is variable, from less than one to over $5 \%$ for all stratigraphic horizons analysed (Table 
2), with Carboniferous limestones characterised by the lowest values. Most samples analysed are characterised by porosity below $5 \%$ but in few cases porosity greater than $10 \%$ was measured (maximum value $25.06 \%$ inGrundy Gorne IG-1 well, the Middle Triassic at a depth of 2,201 m below surface) (Fig. 7A). The average porosity of mudstone rocks is in the range of less than $1 \%$ to almost $8 \%$ (Table 2). Most of the samples analysed are characterised by a porosity of a few percent; only in the Piotrków Trybunalski IG-1 well (the Middle Triassic) are values slightly higher. Permeability measurement was performed for a much smaller number of samples. The samples were taken from depths of 3,000 to $4,500 \mathrm{~m}$ below surface (Fig. $7 \mathrm{~B}$ ). The highest value of permeability $(10.33 \mathrm{mD})$ was recorded for the Lower Triassic carbonate deposits in the Piotrków Trybunalski IG-1 well. All results for mudstones are slightly above than 0 (Table 2; Fig. 7B). Permeability of terrigenous deposits mostly is less than 2 $\mathrm{mD}$, with few exceptions (Permian sandstones in the Komorze-1 well) (Fig. 7B).
Following the petroleum-industry classification, rocks can be qualified based on effective porosity $\left(k_{\mathrm{e}}\right)$ as:

- very low porosity $(\varphi<3.5 \%)$;

- low porosity $(3.5<\varphi<10 \%)$;

- moderate porosity $(10<\varphi<15 \%)$;

- high porosity $(15<\varphi<20 \%)$;

- very high porosity $(\varphi>20 \%)$.

However, this classification cannot be applied to fractured rocks, in view of different characters of potential filtration (Plewa \& Plewa, 1992,Bachleda-Curuś \& Semyrka, 1997; Burzewski et al., 2001; Such, 2002; Tiab \& Donaldson, 2004; Semyrka et al., 2008; Semyrka, 2013).

In consideration of permeability, rocks can be classified as:

- rocks with very high permeability $(\mu>1000 \mathrm{md})$;

- rocks with high permeability $(100<\mu<1000$ $\mathrm{md}$ );

- rocks with good permeability $(10<\mu<100 \mathrm{md})$;

- rocks with low permeability $(1<\mu<10 \mathrm{md})$;

- impermeable (micropermeable) rocks $(\mu<1$ md).

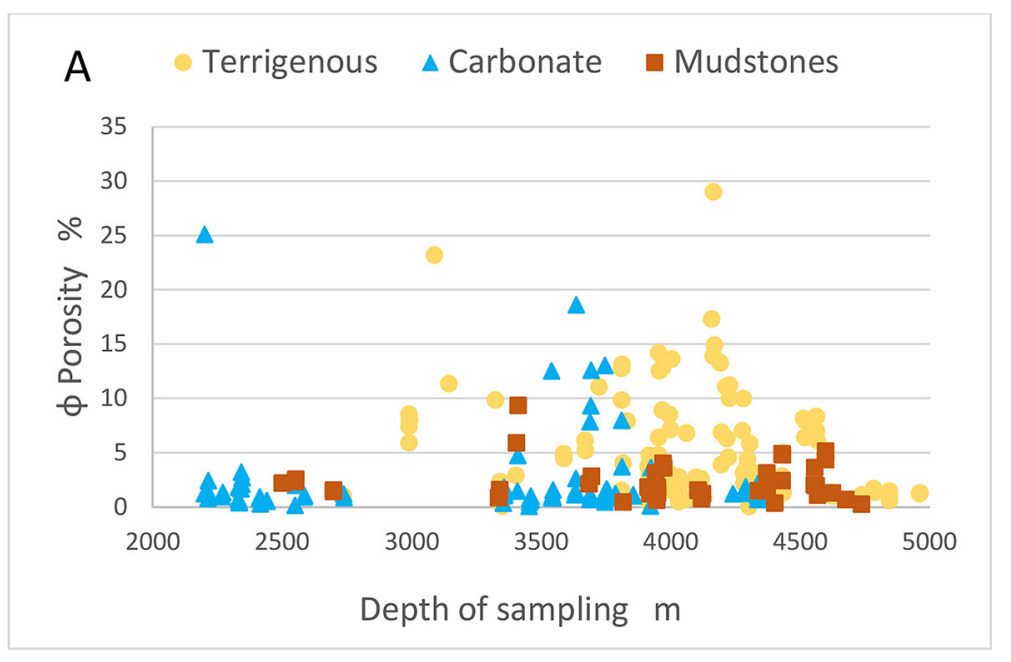

Fig. 7. Distribution of porosity (A) and permeability (B) as a function of sampling depth and facies.

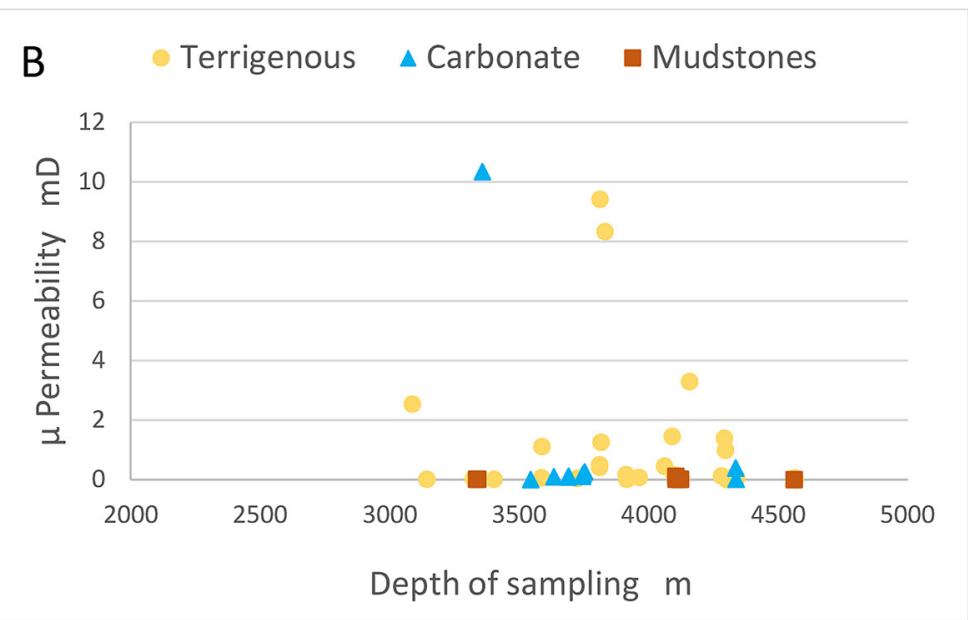




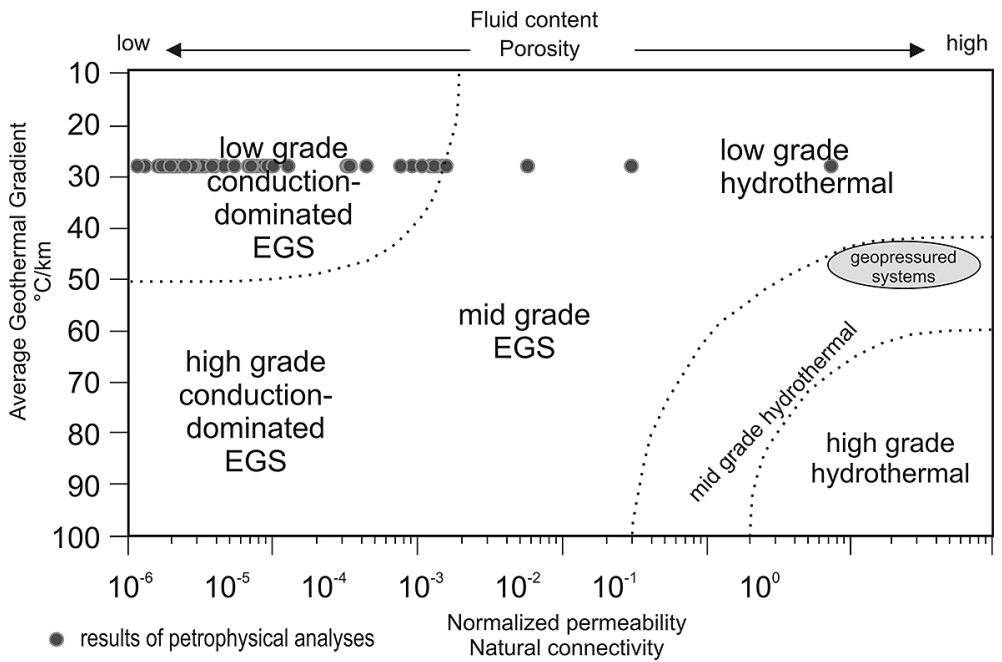

Fig. 8. Continuum of geothermal resources as a function of average temperature gradient, natural connectivity and fluid content. Relative values of permeability $(\mu)$ and porosity $(\varphi)$ indicate effective ranges in natural geological settings. The arbitrary scale for permeability is the ratio between the effective permeability of the entire geothermal system relative to a very permeable unconsolidated sand (adapted from Thorsteinsson et al., 2008).
Three genetic types of reservoir can be distinguished: porous (I), porous-fractured (II) and fractured (III) (Semyrka et al., 2008).

As can be observed in the above analysis, the lithological varieties occurring in the well sections are characterised, for the most part, by very low and low porosity, with predominant porous-fractured and fractured reservoir pore space (Table 2). Relatively increased porosity values, with porous type I reservoir pore space, are seen in Permian deposits.

With the purpose of analysis of results of petrophysical investigation for samples collected from wells in central Poland, functions of average temperature gradient, natural convectivity and fluid content were used (Horne \&Tester, 2014), on which results obtained were superimposed. The geothermal gradient in this region ranges from approximately 21 to $35^{\circ} \mathrm{C} / \mathrm{km}$ (Wójcicki et al., 2013).

For the study area, an average value of $28^{\circ} \mathrm{C} /$ $\mathrm{km}$ was accepted. According to the classification presented above, it was assumed that low porosity values are those under 3.5\% whereas high porosity values are over $20 \%$.

As can be seen from Figure 8, the majority of samples in central Poland have indicated the occurrence of low-grade, conduction-dominated EGS. Samples located outside the area plotted are related to Permian sandstones, the porosity of which attests to the occurrence of low-grade hydrogeothermal resources.

\section{Summary}

Our petrophysical investigations have confirmed that sedimentary rocks in the central part of Poland, at depths between 2,200 and 5,000 m below surface, are characterised by low values of porosity and permeability. Their thermal conditions on site allow us to describe the rocks as prospective for potential development of petrogeothermal energy.

EGS is recognised as a technology of the future, but it is far from being applied. At this stage it is important to recognise a geological reservoir with such a type of geothermal potential. Petrophysical analyses represent one of many ways to assess this in Poland. These studies will provide data on some other relevant parameters, including susceptibility of rocks to fracturing (Horne \& Tester, 2014) which could affect the effectiveness of EGS, i.e., the presence of heterogeneity, clay material and mineralised waters.

\section{Acknowledgements}

The research has been undertaken at the request of the Ministry of the Environment and financed by the National Fund for Environmental Protection and Water Management. The paper prepared under AGH-UST statutory research grant No. 11.11.140.321.

\section{References}

Antkowiak, M., Snyder, N.K. \& Lowry, T.S., 2010. A high level geothermal system scoping model: a first step toward Enhanced Geothermal System Engineering. Proceedings, Thirty-Fifth Workshop on Geothermal Reservoir Engineering, Stanford University, Stanford, 1-8. http:/ / www.geothermal-energy.org/pdf/IGAstandard/ SGW/2010/antkowia.pdf

Bachleda-Curuś, T. \& Semyrka, R., 1997. Zastosowanie analizy porozymetrycznej dla oceny przestrzeni porowej skał w profilach utworów karbonu dolnego i kambru środkowego północno-zachodniej Polski [Application of porosimetric analysis for the assessment of the pore space in the profiles of the 
Lower Carboniferous and Middle Cambrian in the north-western Poland]. Zeszyty Naukowe AGH, Geologia, 23, 155-187 (in Polish).

Brown, D.W., Duchane, D., Heiken, G. \& Hriscu, V.T., 2012. Mining the Earth's Heat: Hot Dry Rock, Geothermal Energy. Springer, 657.

Bujakowski, W. \& Tomaszewska, B. (Eds), 2014. Atlas wykorzystania wód termalnych do skojarzonej produkcji energii elektrycznej i cieplnej w uktadach binarnych w Polsce [Atlas of the possible use of geothermal waters for combined production of electricity and heat using binary systems in Poland]. Wydawnictwo „Jak", Kraków, 307 pp. (in Polish with English extended abstract).

Burzewski, W., Semyrka, R. \& Słupczyński, K., 2001. Kwalifikacja naftowa przestrzeni porowej skał zbiornikowych [Petroleum qualification of the reservoir rock pore space]. Polish Journal of Mineral Resources. Geosynoptics, 3, 185-189 (in Polish).

Čermak, V., 1979. Heat Flow Map of Europe. In: Terrestial Heat Flow in Europe. Springer, 3-40 .

Dadlez, R., Marek, S. \& Pokorski, J. (Eds), 1998. Atlas paleogeograficzny epikontynentalnego permu i mezozoiku $w$ Polsce [Palaegeographical atlas of the epicontinental Permian and Mesozoic in Poland]. Państwowy Instytut Geologiczny, Warszawa, 150 (in Polish).

Doornenbal, J.C., Abbink, O.A., Duin, E.J.T., Dusar, M., Hoth, P., Jasionowski, M., Lott, G.K., Mathiesen, A., Papiernik, B., Peryt, T.M., Veldkamp J.G. \& Wirth, H., 2010. Introduction, stratigraphic framework and mapping. [In:] J.C. Doornenbal \& A.G. Stevenson (Eds): Petroleum Geological Atlas of the Southern Permian Basin Area. EAGE Publications, Houten, 1-9.

Dowgiałło, J., 1969. Występowanie wód termalnych na wybrzeżu i możliwości ich wykorzystania w lecznictwie uzdrowiskowym [The presence of thermal waters on the coast and the possibility of their use in spa treatment]. Balneologia Polska 14, 271-278 (in Polish).

Dowgiałło, J., 1972. Występowanie i perspektywy dalszego występowania wód geotermalnych $\mathrm{w}$ Polsce [Occurrence and prospects for further occurrence of geothermal water in Poland]. Balneologia Polska 17, 193-199 (in Polish).

Dowgiałło, J., Karski, A. \& Potocki, I., 1969. Geologia surowców balneologicznych [Geology of balneological resources]. Wydawnictwa Geologiczne, Warszawa, 295 pp. (in Polish).

EGEC, 2013. Financing Geothermal Energy. Brochure of European Geothermal Energy Council, EGEC Policy Paper, 27.

Gajewska, I., 1997. Trias środkowy (wapień muszlowy - kajper dolny). Trias górny (kajper). Sedymentacja, paleogeografia i tektonika [Middle Triassic (Muschelkalk - Lower Keuper). Upper Triassic (Keuper). Sedimentation, palaeogeography and tectonics]. [In:] S. Marek \& M. Pajchlowa (Eds): Epikontynentalny perm i mezozoik $w$ Polsce [Epicontinental Permian and Mesozoic in Poland]. Prace Państwowego Instytutu Geologicznego 153, 144-171 (in Polish).

Giesche, H., 2006. Mercury porosimetry: A general (practical) overview. Particle \& Particle Systems Characterization 23, 9-19.
Górecki, W., Adamczyk, A.F., Szczepański, A., Szklarczyk, T., Ney, R., Jucha, S., Strzetelski, W., Plewa, M., Łapinkiewicz, A. P., Soboń, J., Banaś, J., Głownia, J., Stypuła, B., Kuźniak, T., Zdżyłowski, W. \& Chylarecki, R., (Eds), 1990. Atlas wód geotermalnych Niżu Polskiego [Atlas of geothermal resources in the Polish Lowlands]. ZSE AGH, Kraków, 369 pp. (in Polish).

Górecki, W., Hajto, M., Augustyńska, J., Jasnos, J. , Kuśmierek, J., Kuźniak, T., Machowski, G., Machowski, W., Nosal, J.,Michna, M., Papiernik, B., Sowiżdżał, A., Stefaniuk, M., Szczygieł, M., Wachowicz-Pyzik, A., Ząbek, G., Rajchel, L., Lemberger, M., Czop, M., Haładus, A., Kania, J., Szczepański, A., Golonka, J., Banaś, J., Mazurkiewicz, B., Solarski, W., Capik, M., Porowski, A., Oszczypko, N., Ostrowski, C., Targosz, P., Wojdyła, M., Barbacki, A., Bielec, B., Bujakowski, W., Hołojuch, G., Kasztelewicz, A., Kępińska, B., Miecznik, M., Pająk, L., Skrzypczak, R., Tomaszewska, B., Budzisz, P., Zastrzeżyńska, J., Herman, Z., Harasimiuk, M., Czerwińska, B., Kubik, B., Pasek, P., Paliychuk, U., Chowaniec, J., Szewczyk, J., Baran, U., Kudrewicz, R., Borsukiewicz-Gozdur, A., Nowak, W., Wiśniewski, S., Kurzydłowski, K. J. \& Kalandyk, K. (Eds), 2013. Atlas geotermalny Karpat Wschodnich [Geothermal Atlas of the Eastern Carpathians]. AGH KSE, Kraków, 791 pp. (in Polish with English summary).

Górecki, W., Kużniak, T., Łapinkiewicz, A.P., Maćkowski, T., Strzetelski, W. \& Szklarczyk, T., (Eds), 1995. Atlas zasobów geotermalnych na Niżu Polskim [Atlas of geothermal resources in the Polish Lowland]. Towarzystwo Geosynoptyków „Geos”, Kraków, 91 pp. (in Polish).

Górecki, W., Sowiżdżał, A. \& Hajto, M. 2012. Występowanie oraz możliwości wykorzystania zasobów wód termalnych i energii geotermalnej w Karpatach [Occurrences and possibilities of using thermal waters resources and geothermal energy in the Carpathians]. [In:] Możliwości wykorzystania zasobów wodnych na obszarze Karpat. Kraków, 80-96 (in Polish).

Górecki, W., Sowiżdżał, A., Hajto, M. \& Jasnos, J., 2013. The latest results of geothermal projects in Poland. Proceedings of European Geothermal Congress, Pisa, Italy, 1-9.

Górecki, W., Sowiżdżał, A., Jasnos, J., Papiernik, B., Hajto, M., Machowski, G., Kępińska, B., Czopek, B., Kuźniak, T., Kotyza, J., Luboń, W., Pełka, G., Zając, A., Szczepański, A., Haładus, A., Kania, J., Banaś, J., Solarski, W., Mazurkiewicz, B., Zubrzycki, A., Luboń, K., Peryt T., Barbacki, A., Pająk, L., Tomaszewska, B., Harasimiuk M., Kurzydłowski, K., Nowak, J., Latour, T., Czerwińska, B., Kudrewicz, R. \& Szewczyk, J. (Eds), 2012. Atlas geotermalny zapadliska przedkarpackiego [Geothermal Atlas of the Carpathian Foredeep]. AGH KSE, Kraków, 381 pp. (in Polish).

Górecki, W., Szczepański, A., Oszczypko, N., Hajto, M., Oszczypko-Clowes, M., Papiernik, B., Kępińska, B., Czopek, B., Haładus, A., Kania, J., Banaś, J., Kurzydłowski, K., Rożniatowski, K., Solarski, W., Mazurkiewicz, B., Kuźniak, T., Machowski, G., Michna, M., Soboń, J., Luboń, W., Pełka, G., Rajchel, L., Sowiżdżał, A., Kotyza, J., Capik, M., Hałaj, E., Harasimuk, M., Bujakowski, W., Barbacki, A., Hołojuch, G., Kaszte- 
lewicz, A., Pająk, L., Tomaszewska, B., Chowaniec, J., Zuber, A., Malata, T., Augustyńska, J., Operacz, T., Freiwald, P., Patorski, R., Witek, K., Czerwińska, B., Gąsiorek, E., Ślimak, C., Wartak, W., Skupien, M., Goryl, M., Cichoń, K., Kudrewicz, R., Budzisz, P., Zastrzeżynska, J. \& Dowgiałło, J. (Eds), 2011. Atlas zasobów wód i energii geotermalnej Karpat Zachodnich [Atlas of geothermal waters and energy resources in the Western Carpathians]. AGH KSE, Kraków, 772 pp. (in Polish with English summary).

Górecki, W., Szczepański, A., Sadurski, A., Hajto, M., Papiernik, B., Kużniak, T., Kozdra, T., Soboń, J., Szewczyk, J., Sokołowski, A., Strzetelski, W., Haładus, A., Kania, J., Kurzydłowski, K., Gonet, A., Capik, M., Śliwa, T., Ney, R., Kępińska, B., Bujakowski, W., Banaś, J., Solarski, W., Mazurkiewicz, B., Pawlikowski, M., Nagy, S., Rajchel, L., Feldman-Olszewska, A., Szamałek, K., Wagner, R., Kozłowski, T., Malenta, Z., Sapińska-Śliwa, A., Sowiżdżał, A., Kotyza, J., Leszczyński, K.P. \& Gancarz, M. (Eds), 2006a. Atlas zasobów geotermalnych formacji mezozoicznej na Niżu Polskim [Atlas of geothermal resources of Mesozoic formations in the Polish Lowlands]. Ministry of Environment, ZSE AGH, Kraków, 484 pp. (in Polish with English summary).

Górecki, W., Szczepański, A., Sadurski, A., Hajto, M., Papiernik, B., Szewczyk, J., Sokołowski, A., Strzetelski, W., Haładus, A., Kania, J., Rajchel, L., Feldman-Olszewska, A., Wagner, R., Leszczyński, K.P. \& Sowiżdżał, A. (Eds), 2006b. Atlas zasobów geotermalnych formacji paleozoicznej na Niżu Polskim [Atlas of geothermal resources of Paleozoic formations in the Polish Lowlands]. Ministry of Environment, ZSE AGH, Kraków, 240 pp. (in Polish with English summary).

Hajto, M. \& Górecki, W., 2005. Geological analysis and assessment of geothermal energy resources in selected Devonian, Carboniferous and Permian reservoirs in the Polish Lowlands. Proceedings of World Geothermal Congress, Antalya, Turkey, 1-6.

Hajto, M. \& Górecki, W., 2010. Potencjał energetyczny wód termalnych na Niżu Polskim [Energy potential of thermal waters in the Polish Lowland]. Biuletyn Państwowego Instytutu Geologicznego 439, 81-85 (in Polish with English summary).

Hillis, R.R., Hand, M., Mildren, S., Morton, J., Reid, P. \& Reynolds, S., 2004. Hot dry rock geothermal exploration in Australia. Proceedings of PESA Eastern Australasian Basins Symposium II, Adelaide, 415-423.

Horne, R.N. \& Tester, J.W., 2014. Geothermal energy an emerging option for heat and power. Bridge the Linking Engineering and Society, Emerging Issues in Earth Resources Engineering 44, 7-15.

Karnkowski, P.H., 2008.Tectonic subdivision of Poland: Polish Lowlands. Przeglad Geologiczny 56, 895-903 (in Polish with English summary).

Kępińska, B., 2015. Geothermal energy country update report from Poland, 2010-2014. Proceedings of World Geothermal Congress, Melbourne, Australia, 1-11.

Kuśmierek, J. \& Semyrka, R., 2003. Zmienność cech zbiornikowych przestrzeni porowo-szczelinowej piaskowców karpackich i ich kwalifikacja naftowa [Variability of reservoir properties of the pore-fracture space in
Carpathian sandstones and their petroleum qualification]. Przeglad Geologiczny 51, 732-743 (in Polish with English summary).

Miecznik, M., Sowiżdżał, A., Tomaszewska, B. \& Pająk, L., 2015. Modelling geothermal conditions in part of the Szczecin Trough - the Chociwel area. Geologos 21, 187-196.

Mizerski, W., 2011. Geologia Polski [Geology of Poland]. Wydawnictwo Naukowe PWN, Warszawa, 287 pp. (in Polish).

Narkiewicz, M. \& Dadlez, R. 2008. Geologiczna regionalizacja Polski - zasady ogólne i schemat podziału w planie podkenozoicznym i podpermskim [Geological regional subdivision of Poland: general guidelines and proposed schemes of sub-Cenozoic and sub-Permian units]. Przeglad Geologiczny 56, 391-397 (in Polish with English summary).

Ney, R. \& Sokołowski, J., 1987. Wody geotermalne Polski i możliwości ich wykorzystania [Geothermal waters of Poland and possibility of their use]. Nauka Polska 6, 67-92 (in Polish).

Papiernik, B., Sowiżdżał, A. \& Ciągło, J. 2008. Możliwości zagospodarowania wód geotermalnych zbiornika cenomańskiego w rejonie Proszowice-Busko-Pińczów [Possibilities of geothermal waters development from the Cenomanian aquifer of the Proszowice-BuskoPińczów area]. Biuletyn Państwowego Instytutu Geologicznego 429, 131-1 (in Polish with English summary).

Plewa, M. \& Plewa, S., 1992. Petrofizyka [Petrophysics]. Wydawnictwa Geologiczne, Warszawa, 327 pp. (in Polish).

Sausse, J., Dezayes, C. \& Genter, A., 2007. From geological interpretation and 3D modelling to the characterization of the deep seated EGS reservoir of Soultz (France). Proceedings of European Geothermal Congress, Unterhaching, Germany. International Geothermal Association - European Branch Publications, 1-7 (https:/ / pangea.stanford.edu/ERE/pdf/IGAstandard/EGC/2007/059.pdf).

Semyrka, R., 2013. Jakościowa i ilościowa charakterystyka petrofizyczna subfacji dolomitu głównego w strefach paleogeograficznych [Quantitative and qualitative petrophysical characteristics of main dolomite subfacies in pleogeographical zones]. Gospodarka Surowcami Mineralnymi 29, 99-115 (in Polish with English summary).

Semyrka, R., Semyrka, G. \& Zych I., 2008. Zmienność parametrów petrofizycznych subfacji dolomitu głównego zachodniej strefy półwyspu Grotowa w świetle badań porozymetrycznych [Variability of petrophysical parameters ob subfacies in the Main Dolomite strata of the western Grotów Peninsula area in the light of porosimetric measurements]. Kwartalnik AGH, Geologia 34, 445-468 (in Polish with English summary).

Sowiżdżał, A., 2010. Perspektywy wykorzystania zasobów wód termalnych jury dolnej z regionu niecki szczecińskiej (północno-zachodnia Polska) w ciepłownictwie, balneologii i rekreacji [Prospects of use of thermal water resources of Lower Jurassic aquifer in the Szczecin Trough (NW Poland) for space heating 
and balneology and recreation]. Przeglad Geologiczny 58, 613-621 (in Polish with English summary).

Sowiżdżał, A., 2012. Potencjat geotermalny niecki szczecińskiej [Geothermal potential of the Szczecin Trough]. GEOS, Kraków, 119 (in Polish with English summary).

Sowiżdżał, A., 2015. Characterization of geothermal reservoirs parameters in Polish part of Carpathian Foredeep. Carpathian Journal of Earth and Environmental Sciences 10, 237-246.

Sowiżdżał, A. \& Kaczmarczyk, M., 2016. Analysis of thermal parameters of Triassic, Permian and Carboniferous sedimentary rocks in central Poland. Geological Journal 51, 65-76.

Sowiżdżał, A., Papiernik, B., Machowski, G. \& Hajto, M., 2013. Characterization of petrophysical parameters of the Lower Triassic deposits in prospective location for Enhanced Geothermal System (central Poland). Geological Quarterly 57, 729-744.

Such, P., 2002. Wykorzystanie porozymetrii rtęciowej w analizie przestrzeni porowej skał zbiornikowych [The use of mercury porosimetry analysis in the pore space of reservoir rocks]. Prace Instytutu Górnictwa Naftowego i Gazownictwa 113, 1-84 (in Polish with English summary).

Szewczyk, J. \& Gientka, D., 2009. Terrestrial heat flow density in Poland: a new approach. Geological Quarterly 53, 125-140.

Szyperko-Teller, A., 1997. Trias dolny (pstry piaskowiec). Sedymentacja, paleogeografia i paleotektonika [Lower Triassic (Buntsandstein). Sedimentation, palaeogeography and palaeotectonics]. [In:] S. Marek \& M. Pajchlowa (Eds): Epikontynentalny perm i mezozoik w Polsce [Epicontinental Permian and Mesozoic in Poland]. Prace Państwowego Instytutu Geologicznego 153, 121-132 (in Polish).
Tenzer, H., 2001. Development of Hot Dry Rock Technology. GHC Bulletin 12, 1-9.

Tester, J.W., Anderson, B.J., Batchelor, A.S., Blackwell, D.D., Dipippo, R., Drake, E.M., Garnish, J., Livesay, B., Moore, M.C., Nichols, K., Petty, S., Toksoz, M.N. \& Veatch, R.W., 2006. The Future of Geothermal Energy. Impact of Enhanced Geothermal Systems (EGS) on the United States in the $21^{\text {st }}$ Century. Massachusetts Institute of Technology (http://geothermal.inel.gov).

Thorsteinsson, H., Augustine, C., Anderson, B.J., Moore, M.C. \& Tester, J.W., 2008. The impacts of drilling and reservoir technology advances on EGS exploitation. Proceedings of the $33^{\text {rd }}$ Workshop on Geothermal Reservoir Engineering, Stanford University, 1-14.

Tiab, D. \& Donaldson, E., 2004. Petrophysics: Theory and Practice of Measuring Reservoir Rock and Fluid Transport Properties. $2^{\text {nd }}$ ed. Gulf Professional Publishing, 889 pp.

Tomaszewska, B. \& Szczepański, A., 2014. Possibilities for the efficient utilisation of spent geothermal waters. Environmental Science and Pollution Research 21, 11409-11417.

Wójcicki, A., Sowiżdżał, A. \& Bujakowski, W. (Eds), 2013. Ocena potencjału, bilansu cieplnego i perspektywicznych struktur geologicznych dla potrzeb zamkniętych systemów geotermicznych (Hot Dry Rocks) $\mathrm{w}$ Polsce [Evaluation of potential, thermal balance and prospective geological structures for needs of unconventional geothermal systems (Hot Dry Rocks) in Poland]. Ministerstwo Środowiska, Warszawa, 246 pp. (in Polish).

Manuscript received: 3 November 2015 Revision accepted: 5 April 2016 